\title{
Service Quality Dimensions, Students' Satisfaction and the Link Between Them: A Study of Student Information System at Jiangsu Province' Universities China
}

\author{
Samar Zaineldeen ${ }^{1 *} \quad$ Li Hongbo $^{1} \quad$ Masud Ibrahim $^{2}$ \\ 1.School of Management, Jiangsu University,xuefu Rd,JinKou,Zhenjiang,Jiangsu, China \\ 2.School of Finance \& Economics, Jiangsu University,xuefu Rd,JinKou,Zhenjiang,Jiangsu, China
}

\begin{abstract}
The Chinese educational system's reputation is remarkable in the region. Graduates from universities in China have played a great role in the development of their countries. The increasing number of students is the most significant challenge facing the higher education sector in China. This study sought to examine the impact of students information system's service quality on students satisfaction among universities in Jiangsu Province in China. Data for the study was obtained from 400 international students sampled across the region of Jiangsu province in China. Findings from this study shows that a rise of 0.485 in empathy will result in increased satisfaction of students in universities. Likewise, an while 0.174 tangibles increase will result in an increase directly in satisfaction of student in universities. Moreover, the satisfaction of students in universities in China will be influenced by Reliability when a 0.165 reliability increase will result in increased directly to satisfaction of student within universities.
\end{abstract}

Keywords: Chinese education, service quality dimentions, student satisfaction .

DOI: $10.7176 /$ EJBM/12-9-04

Publication date:March $31^{\text {st }} 2020$

\section{Introduction}

Universities in China are attracting more international students now more than in the past years which might be due to the opening up of the country in recent times. The universities are therefore in competition to attract the best and quality international students. To achieve this objective, Chinese universities in collaboration with the Chinese governemt are providing attractive incentives in the form of scholarships which are in various categories incluing governmental, provincial and presidential scholarships.

Additionally, the Chinese educational system's reputation is also remarkable in the region. Graduates from universities in China have played a great role in the region to develop many countries. An increasing number of students coupled with inadequate instructors are the most significant challenges facing the Chinese higher education sector. Hence the ratio of students to the instructor will see a rise as the number of students increases. Nevertheless, this may also be seen as an opportunity to attract not only students but also international or foreign instructors.

The rise in the number of students has thus created another issue of how to management students information. Online information system is one of the methods used by higher education institutios to manage students records as well as provide additional services like online registration of courses, admission management, placement of notices, posting timetables and student examination results.

In the discipline of management information system, contentment with IS (Information system) has been the main core of vast research. It mostly used as a substitute measure for IS success Liu \& Khalifa( 2003). With the work of Pearson \& Bailey (1983) user satisfaction research got noticed and it stayed in continuity through Ives et al. (1983), Torkzadeh \& Doll's (1988) work. In their influential work, McLean \& DeLone (1992) gave a detailed model of variables that are used to look upon IS success and that their relationships with each other.

Among the early scholars, we have Lee \& Kettinger (1994) who looked upon Information System service quality as a substitute for Information System success. Service quality was late included as an antecedent of Information System satisfaction and a key measure of Information System success into an updated model of Information System success ( Mcgill et al. 2003).

It has been shown in several studies that university's environment has an effect on the academic achievement of students, and the availability of technological facilities is quite a significant aspect of the environment of the university. Hence, investigating students perception of the effect of service quality of the of the students online system is essential. Parasuraman's SERVQUAL model is adopted as the theretical anchor of this study.

The following are the objectives of this study:

The main aim of this study is to understand the difference in perception of the students toward the quality of service rendered to them. Furthermore, the student satisfaction conceptual basis and perceived quality are discussed and the relationship between student satisfaction and service quality is explored. At last, the most important dimensions of service quality is to the students are determined. This study's attempt to assess the international student 
satisfaction taking in regard to the quality of newly implemented customized student information systems in a large number of Jiangsu province' universities in china Research question: What is the consequence of using the (SIS) Student Information System on student satisfaction?

\section{Literature Review}

\subsection{Students' Satisfaction}

To study user satisfaction 2 main approaches have been followed by researchers. 1 approach concerns the procedure that is involved in satisfaction formation and focuses on understanding the mechanisms that help users to form dissatisfaction and satisfaction. User satisfaction is looked at as a summary outcome in the other approach of consumption experience and has a minimal focus on its formation processes (Jonathan \& Kasper 1995). Toward understanding satisfaction, consumer satisfaction research takes the way of process-oriented approach(Oliver, 1980). Likewise, a considerable number of user satisfaction research have focused on explaining the reasons why users get dissatisfied or satisfied with an IS which uses process-oriented frameworks and theories from the psychology and marketing literature (Todd \& Wixom, 2005).

(Thierry et a.l 1984)describe satisfaction as a fulfillment arising from one's experience of a performance or an outcome that satisfies his/her expectations. Satisfaction is dependent on the customer's expectation level and perceived performance. Still students expectations in the university could go before the time the students got enrolled and earlier than their enrollment at the institution ( Palacio et al. 2002), there's been a debate that the only things that involve in student satisfaction are their perception and the experiences they got in their university during their time there (Khoo, S., et $a l$.) .

Customer satisfaction was seen as a consequence of the assessment of student service basing on a relative perception of delivery of service comparison with their earlier expectations (Petruzzellis et al. 2006). Student satisfaction indicates the subjective evaluation of student favorability of the different experiences and results linked with education (Desarbo \& Oliver, 1989). Where as in 1995, Borden found that the satisfaction of students is associated with a match between campus environment and student priorities. As its stated Wiers- Jenssen in 2002 , "student satisfaction approaches may be a tool for building a bridge between more traditional and academic views on how to improve higher education and more market-orientated perspectives".

To date, most Information System satisfaction studies that have incorporated the different IS components (information, system, and service) into their model have focused on measuring how users perceive the quality of these components (DeLone \& McLean, 2003; Forsgren et al., 2016; Seddon, 1997; Todd and Wixom, 20013) and relating it to user satisfaction. However, the consumer behavior literature has often debated the direction of causality between service quality and satisfaction (Cronin Jr \& Taylor). To illustrate further, quality as a long-term overall assessment of consumption experience and satisfaction as a transaction-specific evaluation was considered (Parasuraman et al. 1988). It was claimed perceptions of higher quality will be a result of a positive evaluation of satisfaction.

\subsection{Quality of Service}

The causality direction between satisfaction and quality of service has been the point to ponder. Quality of service was considered as an overall long-term evaluation of satisfaction and service as a transaction-specific evaluation (Parasuraman 1998). hence, it's claimed perceptions of service quality will be led by a positive evaluation of service satisfaction. Service encounter evaluation was developed by (Bitner 1990 ) and he tested a model in which satisfaction was put forward as a predecessor to service quality. Moreover, Drew and Bolton (1991), tested and proposed a multistage consumers model assessment of the quality of service and value where they draw a direct path to service quality from consumer satisfaction.

On another side, In 1989 Woodside proposed that overall quality maximizes satisfaction. Taylor and Cronin's (1992) model comparison against the SERVQUAL reported that quality of service is the way to satisfaction of consumer despite the claim of Parasuraman (1988). Mackoy and Spreng (1996) investigated the satisfaction and service quality relationship established by Oliver's (1993) modified model. They empirically showed and suggested that the quality of service has a positive and direct relationship with the satisfaction of consumers in which quality of service has a serious impact on satisfaction. Furthermore, Lee et al. (2000) took an attempt to resolve the dispersed findings on the causality direction by the means of gathering data from consulting/ peoplebased firm and equipment/ facility-based service firms. Perceived quality of service, in fact, guides consumer satisfaction was reported. Petrick et al. (2004) explore the service quality, attitude and customer satisfaction relationship. Quality of Service leads to satisfaction and modify attitudes through satisfaction was suggested through their results

Mclean and DeLone (2003) held a follow-up study to incorporate new IS success studies in their model. They put on the quality of service as a predecessor to the satisfaction of the user and intend to use it in the updated model. Building on prior research, Todd and Wixom (2005) combined 2 streams of famous research in Information systems to build their model of satisfaction. They acknowledged user satisfaction is affected by service quality; 
Still, their model didn't include service quality in the model because they focused on measuring fairly general IS characteristics that many systems share and argued that including it would have made their study system-specific. Xu et al. (2013) later incorporated quality of service into Todd and Wixom's (2005) e-service model and tailored it to focus on service-related attributes of the website context in which they evaluated the model.

Significantly institutions' responsibilities for sure one that can have the greatest influence on student failure or success is the provision of services of student support. Hence, it's vital to incorporate quality of service as the factors that have a serious impact on the satisfaction of students with the online information system at their universities.

Parasuraman and colleagues (1988) conducted one of the earliest studies in service quality they introduced 11 dimensions and these dimensions were identified as Responsiveness, Reliability, Credibility, Customization, Access, Competence, Security, Courtesy, Tangibles, Understanding the customer and Communication. But, as these eleven dimensions were intersecting, so thee dimensions were rearranged in the model of SERVQUAL (Parasuraman et al. 1990) which consists of assurance, responsiveness, reliability, empathy, and tangibility.

Service quality definition focuses on the idea that it should be determined upon the users' evaluation. On what the user perceives, the quality's been conceptualized based on that. So, the term perceived quality. Entity experience or general superiority judgment has been described as perceived quality ( Keaveney et al. 1996). Similarly, ( Berry et al. 1990) established that quality perception of service by customers rises from comparing the expectations prior to experiencing the service to their real experience of service. Quality perceived is understood as a sort of attitude in association with satisfaction but not entirely exactly like it, this is deduced from an assessment of (Rowley, 1996) what one expects against what's ones' performance opinion.

SERVQUAL measurement earliest adapters include Lee \& Ketttinger (1994). They adapted it to the IS context. From then, SERVQUAL adaption started to expand in a substantial array of industries. Researchers like Afridi (2016); Arambewela \& Hall (2011); as well as Yousapronpaiboon (2014) who made use of these 5 dimensions to measure the quality of service

Several researchers have found that different dimensions of quality of service play a vital role in determining satisfaction. It's highly critical that to increase the satisfaction level the service providers need to focus even more on these dimensions.

\subsection{Service quality dimensions}

5 proposed dimensions of quality of service (Parasuraman et al 1990) as follows; Reliability, Tangibles, Empathy: performing the desired service accurately, dependably, Assurance consistently and Responsiveness.

Gronroos (1988) also identified 6 good perceived service quality criteria including; behavior and Attitudes, Reliability and trustworthiness, flexibility and access, skills and professionals, Recovery and Reputation and credibility. He further says that the quality of service dimensions can be categorized into 3 categories; technical quality, corporate image, and functional quality. Issues in functional quality are linked to the service provider and recipient and interaction and are usually measured in a subjective manner while the other technical quality is assessed objectively and without any regard to the customer's opinion.

Aspinwall and Owlia (1996) carried out a detailed literature review regarding the quality of service and grouped its attributes into 6 dimensions: - Competence, Tangibles, Attitude Reliability. And, Delivery.

Table 1 gives an outline of the different authors and scales of measurement quality of service and the dimensions.

\begin{tabular}{|l|l|}
\hline Authors & Service quality dominations \\
\hline 5 service quality dimensions were proposed. & Reliability \\
Parasuraman et al (1990) & Empathy. \\
& Tangibles \\
& Assurance \\
& Responsiveness \\
\hline $\begin{array}{l}\text { Gronroos (1988) 6 good perceived quality of } \\
\text { service criteria }\end{array}$ & Behavior and attitude \\
& Trustworthiness and Reliability \\
& Flexibility and Access \\
& Reputation and credibility \\
& Recovery \\
\hline $\begin{array}{l}\text { Aspinwall and Owlia (1996) A detailed } \\
\text { literature review was conducted quality of } \\
\text { service and grouped its attributes in } 6\end{array}$ & Skills and Professionalism \\
dimensions. & Tangibles \\
& Reliability \\
& Delivery \\
\hline
\end{tabular}




\begin{tabular}{|c|c|}
\hline Authors & Service quality dominations \\
\hline Sahney, S., et al. (2004) & $\begin{array}{l}\text { Attitude } \\
\text { Delivery } \\
\text { Competence } \\
\text { Content } \\
\text { Reliability }\end{array}$ \\
\hline $\begin{array}{l}\text { Early SERVQUAL model include } 10 \\
\text { dimensions Parasuraman (1985) }\end{array}$ & $\begin{array}{l}\text { Responsiveness } \\
\text { Reliability } \\
\text { Access } \\
\text { Competence } \\
\text { Communication } \\
\text { Courtesy } \\
\text { Credibility } \\
\text { Tangible } \\
\text { Understanding of customer } \\
\text { Security }\end{array}$ \\
\hline Frost \& Kumar, 2000 & $\begin{array}{l}\text { Responsiveness, Reliability, Assurance, } \\
\text { Empathy, Tangibles, }\end{array}$ \\
\hline Dabholkar et al., 1996 & $\begin{array}{l}\text { Reliability, Physical aspects, Personal } \\
\text { interaction, Policy, Problem solving, }\end{array}$ \\
\hline Haywood-Farmer (1988) & $\begin{array}{l}\text { Processes, Physical facilities, and procedures, } \\
\text { Conviviality, professional and People behavior } \\
\text { Judgment }\end{array}$ \\
\hline Madu \& Madu (2002) & $\begin{array}{l}\text { Features } \\
\text { Performance } \\
\text { structure } \\
\text { reliability } \\
\text { aesthetics } \\
\text { storage capacity } \\
\text { security and system integrity } \\
\text { serviceability } \\
\text { trust } \\
\text { product differentiation and responsiveness } \\
\text { customization } \\
\text { Web store policies } \\
\text { reputation } \\
\text { empathy } \\
\text { assurance }\end{array}$ \\
\hline Wolfinbarger \& Gilly (2003) & $\begin{array}{l}\text { security } \\
\text { reliability } \\
\text { customer service } \\
\text { Web site design } \\
\end{array}$ \\
\hline Zeithaml et al. (2002) & $\begin{array}{l}\text { reliability } \\
\text { Efficiency } \\
\text { fulfillment } \\
\text { responsiveness } \\
\text { privacy } \\
\text { contact } \\
\text { compensation }\end{array}$ \\
\hline
\end{tabular}

In a short note, 5 quality of service dimensions (responsiveness, tangibles, reliability, empathy, assurance,) are considered in this study that influences student satisfaction, so we can identify these factor's potential influence on the education sector of China. These include 5 SERVQUAL model dimensions.

2.3.1 Tangibles

Parasuraman et al. (1994) explained tangibles as physical facilities, it services physical image that will be utilized by consumers to determine quality. These tangibles are related to tools, machines and physical facilities that are used to provide service, in addition to representations of the speed, efficiency, and services of transactions. It was stated (Parasuraman et al., 1994) that tangibles are equally significant as empathy. It was argued by the authors 
that it's advisable to take into consideration including operations opening hours under the dimension of empathy; on top of that, overdraft privileges may be included in the dimension of reliability (Agbor, 2011).

2.3.2 Reliability

Reliability means that service is performed correctly for the first time by an organization (Parasuraman et al., 1994). It also shows that organizations try hard to complete their promises and look forward to results. It's classed as $1^{\text {st }}$ dimension in the service quality model of SERVQUAL. Reliability was ranked first in the service quality model in the studies of (Lam, 2002).

\subsubsection{Responsiveness}

On the otherhnad, responsiveness entails employees' telling consumers exactly when matters will be finalized, providing them with undivided attention, promotion of services and responding to customer requests (Parasuraman et al. 1994).

\subsubsection{Assurance}

Employees' knowledge, courtesy and the capacity to transmit trust and confidence to customers is known as Assurance (Parasuraman et al. 1994). Assurance ranking among quality of service dimensions is different in the researcher's opinion. According to Gronroos assurance comes at first ranking (Flavianet al. 2004)., whilst it was ranked fourth at the author (Parasuraman et al. 1994).Keeping consumers informed in their own language without regard to their nationality, age, and educational level, and listening to them. it is stated by (Parasuraman et al. 1994) that assurance refers to employees' attitude, behavior, and the ability of staff to give confidential, friendly, competent services and courteous.

\subsubsection{Empathy}

Its customers desire to be prioritized by an organization that provides the services. Empathy incorporates being paying, personal attention, providing services and caring to customers (Parasuraman et al. 1994). Empathy's core is to convey the feeling to the customer that they are special and unique. Parasuraman (Parasuraman et al. 1994) states that studies that are quantitative have recognized the quality of service model dimensions using credibility, security, and also the access to get a measure of empathy.

Table 2 shows the adopted service quality dimensions and supporting literature

\begin{tabular}{|l|l|}
\hline Definition & Supporting literature \\
\hline $\begin{array}{l}\text { Reliability The ability of reliability } \\
\text { to deliver service promised } \\
\text { accurately and dependably }\end{array}$ & $\begin{array}{l}\text { Parasuraman et al. (1985, 1988), Kettinger \& Lee(1994), Myers et al. } \\
(1997), \text { Chang \& King (2005), DeLone \& McLean (2003), Halawi et al. } \\
(2008),\end{array}$ \\
\hline $\begin{array}{l}\text { Responsiveness indicates Wto how } \\
\text { responsive, prompt and sensitive a } \\
\text { provider of service is to issues } \\
\text { flagged by consumers. }\end{array}$ & $\begin{array}{l}\text { Parasuraman et al. (1985, 1988), Kettinger \& Lee (1994), Myers et al. } \\
(1997), \text { Gefen \& Keil (1998), DeLone \& McLean (2003), Halawi et al. } \\
(2008)\end{array}$ \\
\hline $\begin{array}{l}\text { Empathy: It includes conveying a } \\
\text { caring sense and individual attention } \\
\text { to consumers }\end{array}$ & $\begin{array}{l}\text { Parasuraman et al. (1988), Kettinger \& Lee (1994), Chang \& King } \\
(2005), \text { Myers et al. (1997), DeLone \& McLean (2003), Petter et al. } \\
(2008)\end{array}$ \\
\hline $\begin{array}{l}\text { Tangibles: It involves all things that } \\
\text { can be observed objectively by } \\
\text { customers e.g., equipment, physical } \\
\text { facilities and service personnel } \\
\text { appearance }\end{array}$ & $\begin{array}{l}\text { Parasuraman et al. (1985, 1988), Kettinger \& Lee (1994), Myers et al. } \\
(1997), \text { DeLone \& McLean (2003), Halawi et al. (2008) }\end{array}$ \\
\hline $\begin{array}{l}\text { Assurance is the courtesy integrity } \\
\text { and knowledge of employee that } \\
\text { inspires confidence and interest in } \\
\text { customers }\end{array}$ & $\begin{array}{l}\text { Parasuraman et al. (1988), Kettinger \& Lee (1994), Myers et al. (1997), } \\
\text { DeLone \& McLean (2003), Halawi et al. (2008), Petter et al. (2008). }\end{array}$ \\
\hline
\end{tabular}

\subsection{The Link between Service Quality and Students' Satisfaction}

There seems to be a confusion between satisfaction and service quality (Storbacka et al. 1994). Liljander et al. (1995) it was stated that satisfaction indicates to insider perspective, the consumer's service experience whilst the result is measured by value received of what the consumer had to give to get something. Satisfaction's an outcome if a 'perception was just as good as the experience' Hunt et al. (1991).

(Mackoy and Spreng 1996) discovered that satisfaction of the customer is the outcome of quality of service, Taylor and (Cronin 1992) performed reciprocity empirical test between the satisfaction of customer and quality of service. Quality of service plays a role in the satisfaction of customer satisfaction was the main discovery in their study, another study focusing on the quality of service relationship with the satisfaction of the customer. (Rosenbaum et al. 1999) made everyone notice that quality of service is a predecessor of the satisfaction of the customer.

This also got support from (Caruana 2002) who said that satisfaction of the customer is acting as a mediator 
in the association between loyalty and quality of service. It was stated by (Yavas et al. 2004) that quality of service acts as a foundation pillar of satisfaction of the customer and it's associated with behavioral consequences like a complaint, loyalty, and word-of-mouth.

The satisfaction of the customer is an objective and an important factor in the success of the organization. Companies that get 'high satisfaction of customer' realize that customers that are highly satisfied give many benefits to them. they'll be less sensitive to price changes and will remain loyal for a longer period of time, they'll buy more services and products over a period time, and they are in favor to other potential customers for the company's services and products (2001, Kotler et al.,). Moreover, In 2009 Arambewela \& Hall said that satisfaction of students plays a not only role but a significant one in the management of market, and it's been noticed to get increased profits, repeated sales, customer loyalty, and most importantly positive word-of-mouth. This is second by (Vinagre \& Neves 2008), who stressed that customers who are satisfied act as significant sources of free advertising by recommendations and referrals, whereas customers who are dissatisfied are far more probable to defect and then convey an experience that is negative to other customers. This discovery highlights organizational success and customer satisfaction relationship. Likewise,Rashid et al. (2009) stated that satisfaction of customer's been found to impact greatly on gaining other customers and corporate image through recommendations.

\subsection{Measurement of Service Quality}

Towards a quality measurement of given service, Parasuraman et al. (1985) are the most notable contributors. Their quality of service model (SERVQUAL) is a multi-item scale made to assess the perception of the customer of the quality of service in retail and service businesses. From 1976-1995 at very least 293 articles have been published and written on quality of service and if an article is considered in which quality of service forms a part of the published articles, it would amount to about 4000 articles (Philip et al. 1997). These figures quite clearly displays the significance of the quality of service attention of research to the topic.

Contrasting to the quality of products and goods, quality of service can't be objectively measured by indicators like defects number and product longevity (Garvin 1983). We have service features that are unique which make service quality subject an elusive one and abstract. Heterogeneity, the inseparability of service consumption and production, service intangibility are included in these features (Parasuraman et al. 1988).

In the report of Parasuraman et al. (1985), many services are not like goods as they are not tangible as they are not objects but performances. When the customer buys products, they can make use of many features that are tangible to evaluate the quality of the product like color, style finishing touches and label. Nonetheless, they can use fewer tangible features and cues when the service quality aspect comes. The availability of cues to customers is mostly limited to service provider representatives and facility features. These services are heterogeneous, and service performance differs depending on the provider of service. Especially, in the case where services are very dependent on labor so there may be a varied performance from one to another representative of service and from one to another day and consumer. Lastly, the consumption and production of a lot of services are mixed. Therefore, service quality can't be engineered facility of production and then get delivered to customers. In a lot of services, quality is occurred and evaluated in the middle of delivery of the service process through provider representative and consumer interaction.

Because of fewer tangible cues, it's tough to measure the quality of service objectively as we do for measuring the quality of the product. So, 1 path to assess the quality of service is to measure the quality of service 36 perceptions. Parasuraman et al. (1988) considered the quality of service perceptions are built through a comparison of the individual between the service firm should offer according to them and their performance of service perception. They go on to the elaborate perceived quality of service as "Attitude or global judgment associating with superior service". A model (SERVQUAL) was proposed including 5 dimensions used to measure the quality of service over industries.

\section{Research Hypotheses}

5 hypotheses are investigated:

H 1: A crucial relationship between satisfaction of student and reliability.

H 2: A crucial relationship between satisfaction of student and tangibility.

H 3: A crucial relationship between satisfaction of student and responsiveness.

H 4: A crucial relationship between satisfaction of student and empathy.

H 5: A crucial relationship between satisfaction of student and assurance.

\subsection{Research Framework}

Figure 1 below displays a model showing the quality of service dimensions effects on the satisfaction of students while making use of the SERQUAL model. 


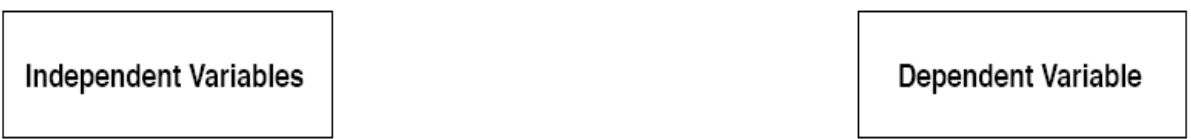

service quality dimensions

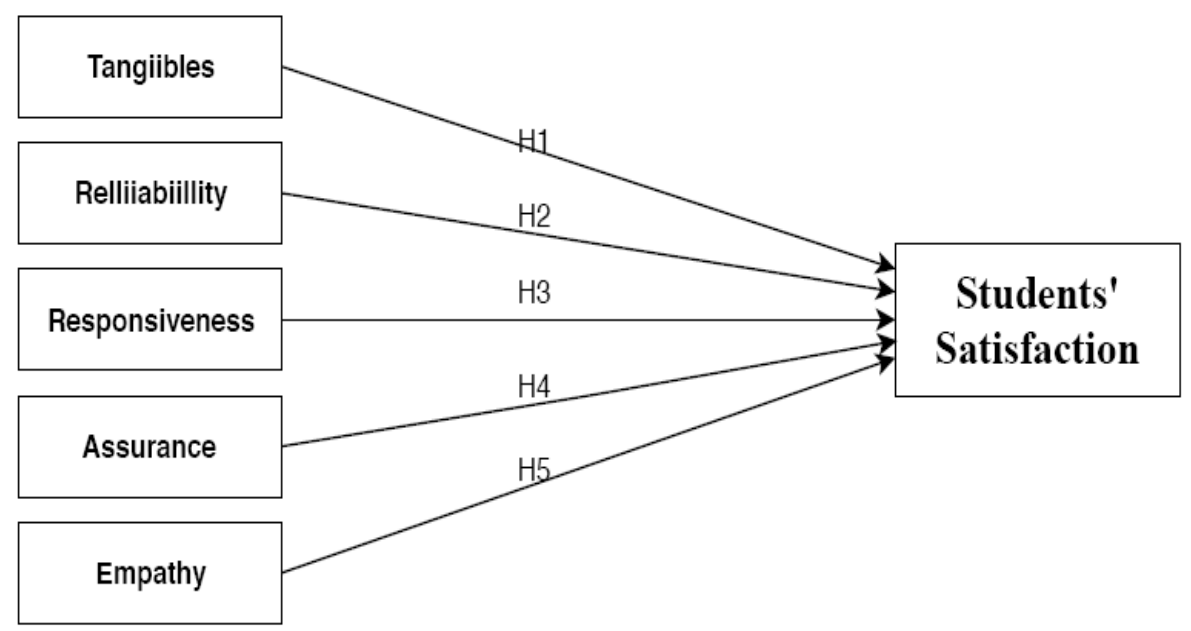

Table 3: Summary of questionnaire

\begin{tabular}{|c|c|}
\hline Dimensions & Items \\
\hline $\begin{array}{l}\text { Tangibles; evidence that is physical and } \\
\text { service representation, and other service } \\
\text { facility customers. }\end{array}$ & $\begin{array}{l}\text { 1. equipment to be up to date } \\
\text { 2. visually appealing physical facilities } \\
\text { 3. design should be attractive } \\
\text { 4. physical facilities appearance must be in line with service types } \\
\text { 5. Well-maintain and modern looking equipment's }\end{array}$ \\
\hline $\begin{array}{l}\text { Reliability: Performance consistency } \\
\text { and accuracy. Dependability, keeping } \\
\text { correct records, service performance at } \\
\text { the designated time }\end{array}$ & $\begin{array}{l}\text { 1. Do things on time } \\
\text { 2. be reassuring and sympathetic when a user encounters a problem } \\
\text { 3. dependable } \\
\text { 4. provide services on the promised time } \\
\text { 5. keep records that are accurate }\end{array}$ \\
\hline $\begin{array}{l}\text { Responsiveness: Readiness or } \\
\text { employees' willingness to provide } \\
\text { service, time punctuality such as calling } \\
\text { the customer back rapidly, giving } \\
\text { prompt service. and mailing a } \\
\text { transaction slip quickly }\end{array}$ & $\begin{array}{l}\text { 1. Expected to inform user about when service will be performed } \\
\text { 2. user expecting prompt service } \\
\text { 3. willing employees to help users. } \\
\text { 4. Employees available when needed } \\
\text { 5. individual attention to each user }\end{array}$ \\
\hline $\begin{array}{l}\text { Assurance: employees ability to inspire } \\
\text { trust, courtesy knowledge }\end{array}$ & $\begin{array}{l}\text { 1. making user confident } \\
\text { 2. Providing a secure and safe transaction with a user } \\
\text { 3. service availability convivence } \\
\text { 4. employees getting enough support to do their jobs best } \\
\text { 5.Employees occupational knowledge }\end{array}$ \\
\hline $\begin{array}{l}\text { Empathy: Firm provides individual } \\
\text { attention to its customers, caring }\end{array}$ & $\begin{array}{l}\text { 1. staff courtesy and friendliness } \\
\text { 2.Understanding users specific needs } \\
\text { 3.attention to each user to know them } \\
\text { 4. convenient operating hours to users } \\
\text { 5. employees expected to know user needs }\end{array}$ \\
\hline $\begin{array}{l}\text { Customer Satisfaction } \\
\text { Satisfied overall with these services }\end{array}$ & $\begin{array}{l}\text { 1. Service representation and physical evidence } \\
\text { 2. Keeping correct records and accuracy } \\
\text { 3.timely services } \\
\text { 4.employeees ability to inspire confidence and trust } \\
\text { 5. staff's courtesy and friendliness }\end{array}$ \\
\hline
\end{tabular}

Source: Collected from; Finn et al. (1991), Parasuraman et al., 1988 


\subsection{Operational Definitions and Research Variables}

This definition stands on the pillars of the literature review. It clarifies the quality of service dimensions effect on the satisfaction of students in Jiangsu Province's universities. We develop research hypotheses and get a theoretical foundation.

\subsubsection{Independent Variables}

Quality of service includes many dimensions that influence the satisfaction of students from the perspective of the student. Its displays the quality of service model with dimensions such as responsiveness, empathy, tangibles, assurance, reliability.

Quality of service model questionnaire was constructed for independent variables following a number of questions: 5 for responsiveness, 4 for tangibility, 5 for assurance, 5 for reliability 5 for empathy. Literature importance determined the respective number of questions

\subsubsection{Dependent Variables}

The satisfaction of students is an assessment of how customers are supplied with the services. To develop techniques and service standards, managers must be willing and try to understand the bridge between customers' expectations and their perception.

Questions related to satisfaction of Students were satisfied with services overall

\section{Methodology}

To test out the proposed model a questionnaire survey was adopted. As claimed by King et al. (2005), since the 1990s, IS scholars have largely used survey questionnaires to assess constructs and relationships. Likewise, IS scholars have used survey questionnaires to study the satisfaction of users (e.g. 1983; Lee \& Kettinger, 1994; Torkzadeh \& Doll 1988; Todd\& Wixom 2005 ) These samples were selected without any regard for gender age and nationality.

Parasuraman's SERVQUAL dimensions was adopted by this study consistent with the prior research on user satisfaction, In this study the dependent is overall international undergraduate and postgraduate students' satisfaction in Jiangsu province' universities with online information system in their universities. The Students' Information system assists the management of student-related information throughout the fundamental business activities i.e. admission, accommodation, examination, registration, grade distribution, the offering of courses, class timetables and records.

The independent variable dimensions were assurance, tangibility, responsiveness, empathy, and reliability as shown in Fig.1.

Data for the study was obtained from 400 international students sampled across the region of Jiangsu province in China.

The major motive is the assessment of the satisfaction of international students with regard to service quality. Quality of service is measured by the implementation of the "SERVQUAL" instrument 5 dimensions: each followed by 4 questions. Scale that's used for all replies is The 5-point Likert ( $2=$ disagree, $3=$ neither agree nor disagree, $4=$ agree $5=$ strongly agree $1=$ strongly disagree).

\subsection{Research Instrument and Data Collection Method}

Parasuraman et al (1990) is the base of the instrument used in this research. 5 dimensions were the foundation of the questionnaire (assurance, tangibility, reliability, empathy, and responsiveness). Likert scale was used from 1 to 5. These questionnaires were given out to different universities located in Jiangsu province, making use of survey methodology and respondents were international undergraduate and postgraduate students identified through a random sampling approach.

\subsection{Statistical Analysis}

For analyzing the data of questionnaires, by using the SPSS software statistical analysis was carried out. Inferences of Stats used are:

- To measure the individual variables Sampling Adequacy KMO was used

- Use of Reliability Analysis, to assess reliability utilizing Cronbach alpha

- To get how much students' Satisfaction is affected by the independent variable we use Regression Analysis. Indication of the contribution of independent variables is also provided.

- For Assessing the most effective independent variables we use stepwise regression analysis which affects the satisfaction of students.

Multiple Regression Analysis the Durbin Watson statistic which tests autocorrelation was calculated and the ANOVA to show that the model is statistically significant.

4.2.1 Reliability and Scales Validity

Individual variable sampling Adequacy was measured by using KMO. Overall of the KMO should be 0.6 or even more for the factor analysis (Özdamar et al. 2017). According to the above results, it revealed that both are 
significant and it is suitable for the factor analysis (See Table 4). The cumulative variance in the table shows $87.10 \%$, which exceeds the minimum acceptance level of $60 \%$ (Özdamar et al. 2017). The table again indicates that Sphericity Bartlett's Test Sphericity is sufficient for correlation between these variables, it shows 14195 and significant $(\mathrm{P}>0.000)$. Whiles the factor loadings of the entire construct exceeded 0.5 (Johnston et al. 1987).

Table (5) KMO and Bartlett's Test

\begin{tabular}{|c|c|c|}
\hline \multicolumn{2}{|c|}{ Kaiser-Meyer-Olkin Measure of Sampling Adequacy. } & $\begin{array}{l}.871 \\
14195.467\end{array}$ \\
\hline \multirow[t]{2}{*}{ Bartlett's Test of Sphericity } & Df & 406 \\
\hline & Sig. & .000 \\
\hline
\end{tabular}

\subsubsection{Analysis of reliability}

The test of reliability is a measure of consistency degree between the variable's multiple measurements. The most used tool of measurement is Cronbach's alpha with 0.6 being the agreed lower limit.

The table below provides a summary of scores of reliabilities. As this table shows, alpha coefficients $>0.6$ which is the required level.

\subsubsection{Regression Analysis}

\begin{tabular}{|l|l|l|}
\multicolumn{3}{c}{ Reliability Table 5 } \\
\hline Variables & Number of Items & Cronbach Alpha \\
\hline Tangibility & 4 & .903 \\
\hline Reliability & 5 & .863 \\
\hline Responsiveness & 5 & .991 \\
\hline Assurance & 5 & .960 \\
\hline Empathy & 5 & .954 \\
\hline
\end{tabular}

This shows or gives how much does each variable that is independent affects the satisfaction of students' that on its own is a dependent variable. One may check out the direct and causal relationship between variables by making use of regression analysis. Plus, on top of that, we can determine the relationship nature between the variables (Aiken et al. 1985).

Model of Stepwise regression is elaborated as a regression model is built step by step iteratively which involves independent variables automatic selection. We can achieve this either by using at a time only one variable that is independent and incorporating it if it's significant statistically in our regression model, or by having each and every potential variables that are independent in the model and those that are not significant statically we can eliminate those, or combing both these methods. Several scholars have recommended This Stepwise regression like Berenson et al. (1992). In the table followed by this SPSS stepwise regression is used to further strengthen the proposed dependent and independent variable relationships. See Table 6

Table (6) Coefficients ${ }^{\mathrm{a}}$

\begin{tabular}{|c|l|l|l|l|l|}
\hline Model & \multicolumn{2}{|l|}{ Unstandardized Coefficients } & $\begin{array}{l}\text { Standardized } \\
\text { Coefficients }\end{array}$ & T \\
\cline { 2 - 6 } & B & Std. Error & Beta & \\
\hline (Constant) & 5.526 & .800 & .144 & 6.909 & .000 \\
Tan & .174 & .082 & .154 & 2.132 & .034 \\
Rel & .165 & .082 & .488 & 2.004 & .046 \\
Emp & .485 & .071 & 6.836 & .000 \\
\hline
\end{tabular}

a. Dependent Variable: SSAT

Shown in the equation below is the Regression Analysis:

Estimated $\mathrm{Y}=\mathrm{a}+\mathrm{b} 1 \mathrm{x}+\mathrm{b} 2 \mathrm{x}+\ldots$,

The dependant variable is $\mathrm{Y}$, $\mathrm{Y}$-intercept is $\mathrm{a}$ or $=\mathrm{a}$ the value of $\mathrm{Y}$ when $\mathrm{x}=0, \mathrm{~b} 1, \mathrm{~b} 2, \ldots$ is the regression coefficients showing the change in $\mathrm{Y}$ given a unit change in $\mathrm{x} 1, \mathrm{x} 2, \ldots \ldots$, and $\mathrm{x} 1, \mathrm{x} 2, \ldots .$. are valued for independent variables.

Depending on stepwise regression shown in the above table, the results are:

Estimated $Y=05.526+0.174 *$ Tangibles $+0.165 *$ Reliability $+0.485 *$ Empathy

Where:

Constant $\mathrm{a}=5.526$

Tangibles Coefficient $=0.174$

Reliability Coefficient $=0.165$

Empathy Coefficient $=0.485$ 
It shows that when all variables are present together, only empathy, Tangibles, and Reliability.

Great impact is shown by this variable on the satisfaction of students in Jiangsu province' universities, whilst the other variables have gone to have an impact equal to nothing. These two are Assurance and Responsiveness.

Empathy with Coefficient $=0.485$ has the highest impact or influence, after that, we have Tangibles variable with Coefficient $=0.174$, while Reliability with Coefficient $=0.165$ influences the least

Results above show Empathy influence on the satisfaction of the student, where a rise of 0.485 in empathy will result in increased satisfaction of students in universities. Likewise, the Tangibles we have in Chinese universities is affected directly by the satisfaction of the student, while 0.174 tangibles increase will result in an increase directly in satisfaction of student in universities. Moreover, the satisfaction of students in universities in China will be influenced by Reliability when a 0.165 reliability increase will result in increased directly to satisfaction of student within universities.

\subsubsection{Multiple Regression Analysis}

The Durbin Watson statistic which tests autocorrelation was calculated to be 1.977 ignoring the presence of autocorrelation. It could be recognized from the table (7), that the R-square is .403 . which indicates that $40.3 \%$ variance is described service quality in student satisfaction. The results in the ANOVA table show that the statistically significant model $(\mathrm{Sig}=.000, \mathrm{P}<0.05)$. The beta value for the Empathy dimension is .485 which indicates that the impact of this dimension is more on the model. Take a look at table $7 \& 8$

Table (7) Model Summary ${ }^{\mathrm{b}}$

\begin{tabular}{|c|c|c|c|c|c|c|c|c|c|c|}
\hline \multirow[t]{2}{*}{ Model } & \multirow[t]{2}{*}{$\mathrm{R}$} & \multirow{2}{*}{$\begin{array}{l}\mathrm{R} \\
\text { Square }\end{array}$} & \multirow{2}{*}{$\begin{array}{l}\text { Adjusted R } \\
\text { Square }\end{array}$} & \multirow{2}{*}{$\begin{array}{l}\text { Std. Error } \\
\text { of the } \\
\text { Estimate }\end{array}$} & \multicolumn{5}{|c|}{ Change Statistics } & \multirow{2}{*}{$\begin{array}{l}\text { Durbin- } \\
\text { Watson }\end{array}$} \\
\hline & & & & & $\begin{array}{l}\text { R Square } \\
\text { Change }\end{array}$ & $\begin{array}{l}\mathrm{F} \\
\text { Change }\end{array}$ & df1 & df 2 & $\begin{array}{l}\text { Sig. F } \\
\text { Change }\end{array}$ & \\
\hline 1 & $635^{\mathrm{a}}$ & .403 & 396 & 3.86729 & .403 & 53.247 & 5 & 394 & .000 & 1.977 \\
\hline
\end{tabular}

a. Predictors: (Constant), Emp, Ass, Tan, Rel, Res

b. Dependent Variable: SSAT

Table (8) ANOVA $^{\mathrm{a}}$

\begin{tabular}{|ll|l|l|l|l|l|}
\hline Model & & Sum of Squares & Df & Mean Square & F & Sig. \\
\hline \multirow{3}{*}{1} & Regression & 3981.787 & 5 & 796.357 & 53.247 & $.000^{\mathrm{b}}$ \\
& Residual & 5892.651 & 394 & 14.956 & & \\
& Total & 9874.437 & 399 & & & \\
\hline
\end{tabular}

a. Dependent Variable: SSAT

\section{Discussion}

EFA was utilized through SPSS in measuring the underlying dimensions associated. For measuring the validity of construct, the test of Sphericity which was developed by Bartlett was used whereas, for measuring the individual variable's sampling adequacy, KMO which stands for Kaiser-Meyer-Olkin was used. Note that the overall of the KMO should be 0.6 or even more for the factor analysis (Özdamar 2017). According to the above results, it revealed that both are significant and it is suitable for the factor analysis (See Table 4). The cumulative variance in the table shows $87.10 \%$, which exceeds the minimum acceptance level of $60 \%$ (Özdamar 2017). The table again indicates that the analysis of Sphericity using the test developed by Bartlett is sufficient for the correlation between the variables. These values represent evidence that there is convergent and discriminate validity.

The estimation of consistency applies to the likeness of different estimation approaches when a similar component is assessed. Table (5) shows ) indicates that latent variables of the model $0.863-0.991$, all over 0.5 . Table (5) uncovers that the Alpha of Cronbach is more noteworthy than 0.70 , and this implies every one of the structures in the table is all the more precisely decided.

Stepwise regression is an alteration of the forward choice to confirm, after each stage where a variable has been presented, if its significance has been diminished beneath the characterized resilience level, all applicant models all the while. On the off chance that an element is recognized, it is excluded from the model. It isn't significant. Great impact is shown by empathy, Tangibles, and Reliability on the satisfaction of students in Jiangsu province's universities. However, the other two variables (Assurance and Responsiveness) had no significant impact and were thus removed.

The R-square indicates that $40.3 \%$ variance is described service quality in student satisfaction. The results in the ANOVA table show that the statistically significant model ( $\mathrm{Sig}=.000, \mathrm{P}<0.05)$.

Results show Empathy influence on the satisfaction of the student, where a rise of 0.485 in empathy will result in increased satisfaction of students in universities. Likewise, the Tangibles we have in Chinese universities are affected directly by the satisfaction of the student, while 0.174 tangibles the increment will bring about an expansion legitimately in fulfillment of students the goal of utilization and understudy fulfillment separately in 
universities. Moreover, the satisfaction of students in universities in China will be influenced by Reliability when a 0.165 reliability increase will result in increased directly to satisfaction of student within universities.

\section{Conclusion}

Aspects of quality of service of students are for a large number of Jiangsu province's universities in china are examined in this study which has an impact on the satisfaction of international students.

The findings of this study suggest the influence of quality of service affects the student's satisfaction that plays a vital role in the success of SIS. Moreover, maintaining the level of the student's satisfaction is a process that needs regular quality of service improvement in the Student Information System.

Establishing these on study findings, we can say that that the perception of international students regarding university quality dimensions e.g "tangibles", "empathy" and "reliability" act as ingredients in building their satisfaction instead of "assurance" and "responsiveness". Relatively stronger satisfaction was predicted by the favorable perception of universities' empathy than tangible and reliability perceptions.

So it's must apply the model of SERVQUAL for the higher education sector in Jiangsu province's universities for service quality measurement in SIS, to meet expectations of the international students.

\section{References}

Afridi, S. A. J. C. U. R. J. (2016). "Measurement of service quality gap in the selected private universities/institutes of peshawar using SERVQUAL model." 6(1).

Agbor, J. M. (2011). The Relationship between Customer Satisfaction and Service Quality: a study of three Service sectors in Umeå.

Aiken, L. S. and G. Stephen (1985). West (1991), Multiple regression: Testing and interpreting interactions, Newbury Park, CA: Sage.

Arambewela, R. and J. Hall (2011). The role of personal values in enhancing student experience and satisfaction : a cross cultural study of international postgraduate students.

Arambewela, R., et al. (2009). "An empirical model of international student satisfaction." 21(4): 555-569.

Bailey, J. E. and S. W. J. M. s. Pearson (1983). "Development of a tool for measuring and analyzing computer user satisfaction." 29(5): 530-545.

Beerli Palacio, A., et al. (2002). "The configuration of the university image and its relationship with the satisfaction of students." 40(5): 486-505.

Berenson, M. L. and D. M. Levine (1992). Basic Business Statistics (Annotated Instructor's Edition), Englewood Cliffs, New Jersey, Prentice Hall.

Bitner, M. J., et al. (1990). "The service encounter: diagnosing favorable and unfavorable incidents." 54(1): 7184.

Bolton, R. N. and J. H. J. J. o. c. r. Drew (1991). "A multistage model of customers' assessments of service quality and value." 17(4): 375-384

Borden, V. M. (1995). "Segmenting student markets with a student satisfaction and

priorities survey." Research in Higher Education: pp. 73-88.

Caruana, A. J. E. J. o. M. (2002). "Service Loyalty: The Effects of Service Quality and the Mediating Role of Customer Satisfaction." 36(7/8): 811-828.

Chang, J. C.-J. and W. R. J. J. o. M. I. S. King (2005). "Measuring the performance of information systems: A functional scorecard." 22(1): 85-115.

Chung, S., et al. (2000). "Complementarity, status similarity and social capital as drivers of alliance formation." 21(1): 1-22.

Cronin Jr, J. J. and S. A. J. J. o. m. Taylor (1992). "Measuring service quality: a reexamination and extension." 56(3): 55-68.

Dabholkar, P. A., et al. (1996). "A measure of service quality for retail stores: scale development and validation." 24(1): 3 .

DeLone, W. H. and E. R. J. I. s. r. McLean (1992). "Information systems success: The quest for the dependent variable." 3(1): 60-95.

Doll, W. J. and G. J. M. q. Torkzadeh (1988). "The measurement of end-user computing satisfaction." 259-274.

Finn, D. W. and W. J. A. i. c. r. Charles Jr "Lamb (1991), “An Evaluation of the SERVQUAL Scales in a Retailing Setting,“." 18(483): 90

Flavian, C., et al. (2004). "Corporate image measurement: A further problem for the tangibilization of Internet banking services." 22(5): 366-384.

Forsgren, N., et al. (2016). "The integrated user satisfaction model: Assessing information quality and system quality as second-order constructs in system administration." 38: 803-839.

Frost, F. A. and M. J. J. o. S. M. Kumar (2000). "INTSERVQUAL-an internal adaptation of the GAP model in a large service organisation." 14(5): 358-377. 
Garvin, D. A. J. C. m. r. (1983). "Spin-offs and the new firm formation process." 25(2): 3-20.

Gefen, D. and M. J. A. S. D. Keil (1998). "The impact of developer responsiveness on perceptions of usefulness and ease of use: An extension of the technology acceptance model." 29(2): 35-49.

Gronroos, C. J. R. o. b. (1988). "Service quality: The six criteria of good perceived service." 9(3): 10.

Halawi, L. A., et al. (2008). "An empirical investigation of knowledge management systems' success." 48(2): 121135.

Haywood-Farmer, J. (1988). "A Conceptual Model of Service Quality." International Journal of Operations \& Production Management Vol. 8 No. 6: pp. 19-29.

Helena Vinagre, M. and J. J. I. j. o. h. c. q. a. Neves (2008). "The influence of service quality and patients' emotions on satisfaction." 21(1): 87-103.

Hunt, H. K. J. J. o. s. i. (1991). "Consumer satisfaction, dissatisfaction, and complaining behavior." 47(1): $107-$ 117.

Ives, B., et al. (1983). "The measurement of user information satisfaction."

Johnston, M., et al. (1987). Motivation and supervision of the sales force, working paper.

Jonathan, J. B. and G. M. Kasper (1995). User (dis)satisfaction and discrepancy in information systems: an integrated model and empirical investigation.

Kettinger, W. J. and C. C. J. D. s. Lee (1994). "Perceived service quality and user satisfaction with the information services function." 25(5-6): 737-766.

Khoo, S., et al. "Service quality and student/customer satisfaction in the private tertiary education sector in Singapore." 31(4): 430-444.

King, W. R. and J. J. C. o. t. A. f. I. S. He (2005). "External validity in IS survey research." 16(1): 45.

Kotler, P. (2001). Principles of Marketing: Physical Distribution \& Logistics Management, New York.

Lam, T. K. J. J. o. M.-F. M. (2002). "Making sense of SERVQUAL's dimensions to the Chinese customers in Macau." 5(1): 43-58.

Liljander, V., et al. (1995). "The nature of customer relationships in services." 4(141): 67.

Liu, V. and M. J. J. o. t. a. f. i. s. Khalifa (2003). "Determinants of satisfaction at different adoption stages of Internet-based services." 4(1): 12.

Madu, C. a. M., A. (2002). "Dimensions of e-quality." International Journal of Quality \& Reliability Management Vol. 19 No. 3: pp. 246-258.

Mcgill, T., et al. (2003). User Developed Applications and Information Systems Success: A Test of DeLone and McLean's Model.

Myers, L. B. and A. J. B. J. o. H. P. Vetere (1997). "Repressors' responses to health-related questionnaires." 2(3): 245-257.

Oliver, R., \& Swan, J. (1989). " Consumer Perceptions of Interpersonal Equity and Satisfaction in Transactions: A Field Survey Approach." Journal of Marketing.

Oliver, R. L. J. J. o. m. r. (1980). "A cognitive model of the antecedents and consequences of satisfaction decisions." 17(4): 460-469.

Owlia, M. S. and E. M. J. Q. A. i. E. Aspinwall (1996). "A framework for the dimensions of quality in higher education." 4(2): 12-20.

Özdamar, Ş., et al. (2017). "Petrology of the shoshonitic Çambaşı pluton in NE Turkey and implications for the closure of the Neo-Tethys Ocean: Insights from geochemistry, geochronology and Sr-Nd isotopes." 284: 477-492.

Parasuraman, A., et al. "A Conceptual Model of Service Quality and Its Implications for Future Research." 49(4): 41-50.

Parasuraman, A., et al. (1994). "Reassessment of expectations as a comparison standard in measuring service quality: implications for further research." 58(1): 111-124.

Parasuraman, A., et al. (1988). "SERVQUAL: A Multiple-Item Scale for Measuring Consumer Perceptions of Service Quality." 64(1): 12-40.

Petrick, J. F. and S. J. J. J. o. T. R. Backman (2004). "Using Square Measures of Perceived Value to Fill Round Holes in the Service Literature-Why Product-Based Measures Are Inadequate for Tourism Research: A Response to Al-Sabbahy, Ekinci, and Riley." 42(4): 429-431.

Petruzzellis Luca, A. M. D. U., Salvatore Romanazzi (2006). "Student satisfaction and quality of service in Italian universities,Managing Service Quality." Vol. 16 No. 4: pp. 349-364

Petter, S., et al. (2008). "Measuring information systems success: models, dimensions, measures, and interrelationships." 17(3): 236-263.

Philip, G., et al. (1997). "The measurement of service quality: a new PCP attributes model." 14(3): 260-286.

Rashid, W. E. W. and H. K. J. J. I. J. o. H. C. Q. Assurance (2009). "Service quality in health care setting." 22(5): 471-482.

Rosenbaum, S., et al. (1999). What makes strategic usability fail?: lessons learned from the field. 
Rowley, J. J. Q. a. i. e. (1996). "Motivation and academic staff in higher education." 4(3): 11-16.

Sahney, S., et al. (2004). "A SERVQUAL and QFD approach to total quality education: A student perspective." 53(2): 143-166.

Seddon, P. B. J. I. s. r. (1997). "A respecification and extension of the DeLone and McLean model of IS success." 8(3): 240-253.

Spreng, R. A. and R. D. J. J. o. r. Mackoy (1996). "An empirical examination of a model of perceived service quality and satisfaction." 72(2): 201-214.

Storbacka, K., Strandvik, T. and Grönroos, C. (1994). "Managing Customer Relationships for Profit: The Dynamics of Relationship Quality." International Journal of Service Industry Management Vol. 5 No. 5: pp. 21-38.

Thierry, H. J. P. D., Hk. Thierry, Ch. J. de Wolff, Handbook of Work and O. Psychology (1984). "Motivation and satisfaction." 4: 253-289.

Wiers-Jenssen, J. S., Bjørn; Grøgaard, Jens B. (1 July 2002). "Student Satisfaction: towards an empirical deconstruction of the concept." Quality in Higher Education Volume 8, Number 2.

Wixom, B. H. and P. A. J. I. s. r. Todd (2005). "A theoretical integration of user satisfaction and technology acceptance." 16(1): 85-102.

Wolfinbarger, M. and M. C. J. J. o. r. Gilly (2003). "eTailQ: dimensionalizing, measuring and predicting etail quality." 79(3): 183-198.

Woodside, A. G., et al. (1989). "Linking sort/ice anlity, customer satisfaction, and behavioral intention." 9(4): 517.

$\mathrm{Xu}$, J., et al. (2013). "Integrating service quality with system and information quality: an empirical test in the eservice context." 777-794.

Yavas, B. F., et al. "A Study of Correlation Between International Equity Markets Using Exchange-Traded Funds." 5(3): 67-82.

Yousapronpaiboon, K. J. P.-S. and B. Sciences (2014). "SERVQUAL: Measuring higher education service quality in Thailand." 116: 1088-1095.

Zammuto, R. F., et al. (1996). "Rethinking student services: assessing and improving service quality." 7(1): 4570.

Zeithaml, V. A., et al. (1990). Delivering quality service: Balancing customer perceptions and expectations, Simon and Schuster.

Zeithaml, V. A., et al. (2002). "Service quality delivery through web sites: a critical review of extant knowledge." 30(4): 362-375. 